\title{
Program "Pilar" untuk Meningkatkan Pengetahuan dan Keterampilan Ibu Menyampaikan Prevensi Kekerasan Seksual Anak
}

\author{
Nurhuzaifah Amini ${ }^{1}$ \& Ira Paramastri ${ }^{2}$ \\ 1,2Fakultas Psikologi Universitas Gadjah Mada
}

\begin{abstract}
The number of negative impacts caused by CSA makes it still need serious treatment. Mother as the closest environment of early childhood should be able to be a preventive agent of CSA. In fact, there was still many mothers who do not have knowledge dan skill regarding CSA prevention on children. Therefore, a program was needed to improve the knowledge and skills of parents through the "PILAR" program (Skilled-Taught Self Protection Skill). This study aimed to validate the "PILAR" program through content validation with professional judgement and empirical validation with training using the one pretest and posttest group design. The result showed that knowledge about CSA prevention improves significantly after being given training with $Z=-2.952, p=0.003(p<0.01)$ and CSA prevention skills improve significantly with $Z=-2.952, p=0.003(p<0.01)$. It meant that the program of "PILAR" was able to improve the knowledge and skills of mothers in performing prevention of CSA.
\end{abstract}

Keywords: CSA prevention; knowledge; PILAR program; skills

\begin{abstract}
Abstrak. Banyaknya dampak negatif yang ditimbulkan kekerasan seksual anak (KSA) menjadikan KSA masih membutuhkan penanganan yang serius. Sebagai orang terdekat anak, ibu seharusnya dapat menjadi agen pencegahan KSA. Faktanya, masih banyak ibu yang belum memiliki pengetahuan dan keterampilan terkait prevensi KSA pada anak. Oleh karena itu, dibutuhkan program untuk meningkatkan pengetahuan dan keterampilan orangtua melalui program "PILAR" (Terampil Ajari Perlindungan Diri). Penelitian ini bertujuan untuk memvalidasi program "PILAR" dengan validasi isi melalui professional judgement dan validasi empirik melalui pelatihan dengan menggunakan desain the one group pretest and posttest. Partisipan yang dilibatkan terdiri dari ibu yang mempunyai anak usia 4-6 tahun, pendidikan minimal SMA, berdomisili Malang dan belum pernah mengikuti pelatihan pencegahan KSA. Partisipan sebanyak 11 orang. Pengetahuan terkait prevensi KSA meningkat secara signifikan setelah diberi pelatihan yakni $Z=-2,952, p=0,003(p<0,01)$ dan keterampilan menyampaikan prevensi KSA juga meningkat secara signifikan dengan $Z$ $=-2,952, p=0,003(p<0,01)$. Hasil penelitian ini menunjukkan bahwa program "PILAR" terbukti dapat meningkatkan pengetahuan dan keterampilan ibu dalam menyampaikan prevensi KSA.
\end{abstract}

Kata kunci: keterampilan; pengetahuan; prevensi KSA; program Pilar

Kasus kekerasan seksual anak (KSA) masih menjadi masalah yang serius di Indonesia. Hal ini dibuktikan dengan ang-

${ }^{1}$ Korespondensi mengenai artikel ini dapat dilakukan melalui nurhuzaifahamini@gmail.com

2atau melalui ira_paramastri@ugm.ac.id+ ka KSA yang tetap tinggi tiap tahunnya. Data yang diperoleh dari Komisi Perlindungan Anak Indonesia (KPAI) menunjukkan bahwa selama tahun 2011 hingga tahun 2016, perbedaan jumlah kasus tiap tahunnya cenderung tipis. 
Sepanjang tahun 2011 hingga 2016, pertahunnya terdapat 5.327 kasus KSA yang terlaporkan (KPAI, 2016).

Kota Malang merupakan salah satu kota dengan angka KSA tertinggi beberapa tahun terakhir di Indonesia. Data yang diperoleh dari Polres Malang (Noval, 2018) menunjukkan bahwa jumlah kasus KSA di kota Malang dalam dua tahun terakhir mengalami peningkatan. Sepanjang tahun 2017 ditemukan sebanyak 277 kasus KSA, awal 2018 khususnya pada bulan pertama dan kedua ditemukan 37 kasus KSA.

KSA merupakan kegiatan seksual yang melibatkan anak yang usianya belum cukup dewasa dengan orang yang usianya lebih tua (Odhayani, Watson \& Watson, 2013). Anak dijadikan alat untuk mendapatkan sensasi senang dalam aktivitas seksual (Olafson, 2011). Bentuk kekerasan seksual terdiri atas dua jenis yakni yang melibatkan kontak fisik dan yang tidak melibatkan kontak fisik. Tindakan kontak meliputi menyentuh secara seksual berbagai area tubuh sensitif anak seperti payudara dan alat kelamin serta seks oral, anal hingga penetrasi. Adapun yang tidak melibatkan kontak mengacu pada tindakan seperti anak yang dipaksa berpose telanjang, memperlihatkan ketika masturbasi, memperlihatkan anak materi pornografi dan melihat orang lain berhubungan (Kisanga, 2012).

Dampak yang ditimbulkan oleh KSA terbagi atas dua kategori yakni fisik dan psikologis. Dampak fisik diantaranya adalah sakit pada vagina atau penis, luka memar, eritema, disuria kronis, enuresis, konstipasi atau enkopresis (Indriati, 2001). Sedangkan dampak psikologis akibat KSA diantaranya stres, depresi, post traumatic stress disorder (PTSD), rasa takut dan cemas yang tinggi, dan perubahan emosi yang tidak stabil (Berhane, et al., 2011;
Cashmore \& Shackel, 2014; Scimeca, et al., 2014).

Finkelhor, Shattuck, Turner, dan Hamby (2014) yang menyatakan bahwa anak dalam rentan usia berapapun berisiko mengalami kekerasan seksual, termasuk anak usia dini. Anak usia dini masih dalam proses perkembangan yaitu anak memiliki ketergantungan yang tinggi pada orang dewasa dan belum memiliki pengertian yang kompleks tentang segala bentuk perlakuan yang mampu mengancam dirinya (Komalasari, 2016). Oleh karena itu, ibu yang memiliki anak usia dini memiliki tanggung jawab dan kewajiban melindungi anak yang sangat besar. Hal ini didukung oleh Yafie (2017) yang menyatakan bahwa lingkungan keluarga merupakan menjadi pendidik utama terkait seks bagi anak, sedangkan pihak lain seperti sekolah hanya sebagai pelengkap dalam mendidik anak.

Realitanya masih banyak ibu yang
tidak memiliki pengetahuan dan
keterampilan dalam mengajarkan anak
prevensi KSA. Hal ini ditunjukkan dengan
adanya temuan bahwa kebanyakan ibu
saat ini masih minim pengetahuan terkait
prevensi KSA. Chalya, Mlekwa,
Nyamhanga dan Urassa (2016)
menyatakan bahwa pengetahuan ibu
terkait prevensi KSA sangat buruk.

Salah satu program yang telah terbukti efektif dapat meningkatkan pengetahuan serta keterampilan orangtua dalam menyampaikan prevensi KSA adalah program "Lingkaran" (Mardhiyah, 2017). Program "Lingkaran" merupakan hasil modifikasi dari program "Jari Peri" oleh Islawati dan Paramastri (2015) yang ditujukan untuk guru, kemudian dimodifikasi dengan menyesuaikan pada kebutuhan orang tua. Namun, dari hasil analisis penelitian Mardhiyah (2017) diketahui bahwa ternyata masih ada beberapa orang tua yang belum 
memahami pentingnya menggunakan media pembelajaran pada saat melakukan edukasi KSA pada anak dan belum semua peserta melibatkan media pendukung dalam proses pembelajaran. Padahal secara teoretis penggunaan media pendukung dalam kegiatan pembelajaran anak usia dini sangat memengaruhi efektivitas dan proses pembelajaran (Brown, 1973).

Oleh karena itu, program "PILAR" (Terampil Ajari Perlindungan Diri) merupakan pengembangan dari program "Lingkaran" yang bertujuan untuk meningkatkan pengetahuan dan keterampilan orang tua khususnya ibu dalam menyampaikan prevensi KSA, dengan menekankan pentingnya penggunaan media pendukung. Pengetahuan merupakan informasi yang diperoleh dari proses penginderaan (Hunt, 2003). Pengetahuan yang diperoleh dari pemberian tugas kemudian diaplikasikan akan menciptakan sebuah keterampilan (Bartholomew, Gottlieb, Kok \& Parcel, 2006). Keterampilan merupakan penerapan dari pengetahuan yang diperoleh dari proses belajar (Ogunfowokan \& Fajemilehin, 2012). Melalui tahapan proses pembelajaran instruksi, demonstrasi, simulasi, melalui umpan balik, serta penguatan maka pengetahuan dapat diubah menjadi keterampilan (Miltenberger, 2012).

Dalam teori pembelajaran Bandura (1986), pengetahuan merupakan proses kognitif yang diperoleh dari hasil pengamatan sedangkan keterampilan merupakan hasil pembentukan perilaku yang diperoleh dari proses belajar melalui pengamatan pada model. Informasi yang diterima dari pengamatan secara visual diinternalisasi dalam proses kognitif membentuk pengetahuan, kemudian pengetahuan yang diproses secara sadar yang membentuk perilaku yang diinginkan. Konsekuensi positif yang diperoleh terhadap pengetahuan akan menjadi penguatan untuk pembentukan perilaku baru (Walsh \& Brandon, 2012). Perilaku tersebut akan terus berkembang menjadi keterampilan apabila selalu mendapatkan penguatan dan dilakukan secara konsisten.

Penyusunan program "PILAR" menggunakan teori pembelajaran observasional Bandura (1986) yang terdiri dari empat tahap yakni: a) atensi, b) retention process, c) motor reproduction process, dan d) motivational process. Proses atensi merupakan proses awal dalam pembelajaran observasional. Pada proses ini pengamat menaruh perhatian terhadap model untuk mengidentifikasi perilaku yang akan ditiru. Retention merupakan proses mengingat semua informasi yang diperoleh secara visual dalam bentuk memori.

Motor reproduction process atau produksi perilaku adalah proses mengubah representasi simbol baik yang berupa gambar maupun kata menjadi perilaku. Teori belajar sosial menjelaskan bahwa manusia tidak mereproduksi seluruh perilaku yang diamatinya. Dalam penelitian ini, motivational process dapat dilihat ketika orang tua diberi kesempatan untuk menyampaikan feedback atas proses pelatihan yang dilakukan.

Untuk melatih terbentuknya keterampilan digunakan teknik behavioral skills training (Miltenberger, 2012). Tahapan proses pembelajaran observasional yang dipadukan dengan teknik behavioral skills training efektif untuk meningkatkan pengetahuan dan keterampilan (Egemo-Helm et al., 2006; Reisener, Gadke, Ho, \& Jostad, 2014).

Teknik behavioral skills training terdiri dari empat aspek yakni: a) modelling, b) instruction, c) rehearsal, dan d) feedback. Modelling merupakan salah satu cara belajar dengan menggunakan model sebagai media untuk menyampaikan 
informasi atau menunjukkan perilaku benar sehingga anak memperoleh pengetahuan dan belajar cara berperilaku yang tepat dengan mengamati dan mencontoh dari model. Instruction merupakan cara untuk digunakan untuk menjelaskan petunjuk atau langkah yang perlu dilakukan agar dapat menguasai dan melakukan keterampilan atau perilaku tertentu secara tepat. Instruksi dapat diberikan secara tertulis maupun verbal. Instruksi yang efektif bersifat spesifik dan deskriptif. Dalam hal ini, instruksi yang diberikan pada anak bertujuan agar anak memahami dengan jelas hal situasi berbahaya yang mengancam dirinya dan hal yang harus dilakukan oleh anak untuk melindungi dirinya.

Rehearsal merupakan upaya memberikan kesempatan kepada anak untuk berlatih mempraktikkan perilaku target sesuai contoh dan instruksi dari model. Feedback atau pemberian umpan balik dilakukan oleh orang tua setelah anak mempraktikkan perilaku target. Umpan balik yang diberikan dapat berupa penguatan atau koreksi. Penguatan yang diberikan merupakan sesuatu yang disukai oleh anak.

Proses pengembangan program "PILAR" dilakukan berdasarkan alur sistematis penyusunan modul menurut Russell \& Johanningsmeier \& (1981). Menurut Russell \& Johanningsmeier (1981), proses penyusunan modul melibatkan enam langkah, mulai dari penentuan tujuan spesifik, penyusunan tes atau instrumen evaluasi, analisis karakteristik pembelajar, penentuan media dan aktivitas belajar, pelaksanaan uji coba (try out) modul dan evaluasi. Adapun program "PILAR" terdiri dari beberapa sesi yakni: a) sesi pengenalan program, b) sesi I pengetahuan kekerasan seksual terhadap anak (KSA), c) sesi II peran orang tua sebagai agen prevensi
KSA, d) sesi III prevensi KSA untuk anak usia dini, d) sesi IV ibu terampil sampaikan prevensi KSA, dan e) penutup.

Penelitian ini bertujuan untuk menguji pengaruh program "PILAR" pada peningkatan pengetahuan dan keterampilan ibu dalam menyampaikan prevensi KSA kepada anak usia dini. Hipotesis penelitian ini adalah program "PILAR" dapat meningkatkan pengetahuan dan keterampilan dalam menyampaikan prevensi KSA kepada anak. Hasil penelitian diharapkan dapat memberikan kontribusi bagi masyarakat, instansi kesehatan dan pendidikan sebagai salah satu bentuk program preventif tahap primer untuk permasalahan KSA. Manfaat lainnya dalam penelitian adalah untuk meningkatnya pengetahuan dan keterampilan ibu dalam menyampaikan prevensi KSA kepada anak.

\section{Metode}

Variabel tergantung dalam penelitian ini adalah pengetahuan dan keterampilan ibu menyampaikan prevensi KSA, sedangkan variabel bebasnya adalah program "PILAR" (Terampil Ajari Perlindungan Diri). Pengetahuan prevensi KSA merupakan merupakan informasi terkait pengetahuan prevensi KSA dan cara perlindungan diri pada anak usia dini yang diperoleh dari proses belajar mengamati. Adapun keterampilan menyampaikan prevensi KSA yang dimaksudkan adalah kemampuan yang terbentuk dari proses pembelajaran observasional, yang diwujudkan dalam beberapa bentuk perilaku.

Partisipan yang terlibat berjumlah 11 ibu yang mempunyai anak usia dini di Kota Malang dengan menggunakan teknik purposive sampling. Adapun karakteristik partisipan yang digunakan adalah ibu yang memiliki anak usia 4-6 
tahun, pendidikan minimal SMA, domisili di Malang, bersedia untuk mengikuti seluruh rangkaian program "PILAR", belum pernah mengikuti pelatihan pencegahan KSA dan memiliki skor pengetahuan terkait prevensi KSA berada pada kategori sedang berdasarkan skala tes pengetahuan.

Pengukuran pengetahuan dalam validitas empirik program "PILAR" menggunakan tes pengetahuan oleh Mardhiyah (2017) yang terdiri dari 34 aitem pengetahuan tentang prevensi KSA dengan nilai content validity ratio sebesar 0,52 sampai 0,92 dan Koefisien alpha Cronbach 0,918. Adapun pengukuran keterampilan menggunakan lembar observasi behavioral skills training oleh Yandu (2017) yang terdiri dari 18 indikator perilaku dengan validitas aitem 0,865 sampai 0,927 dan nilai intraclass correlation coefficient $r$ sebesar 0,899 . Selain kedua alat ukur tersebut, digunakan juga lembar observasi pembelajaran tiap partisipan, lembar evaluasi pelatihan dari partisipan dan observer, self report serta wawancara sebagai instrumen pendukung.

\section{Hasil}

Proses validasi program "PILAR" melalui dua tahap yakni validasi isi dan validasi empirik (Russel \& Johanningsmeier, 1981). Validasi isi program melibatkan empat orang ahli untuk memberikan penilaian terhadap kesesuaian isi modul dengan tujuan yang ingin dicapai oleh modul. Para ahli yang dilibatkan terdiri dari praktisi dan akademisi yang memiliki ketertarikan dan pengalaman terhadap masalah kekerasan seksual anak serta perkembangan anak usia dini. Hasil penilaian dari para ahli terhadap program "PILAR" dianalisis menggunakan Aiken's $V$ (Azwar, 2017). Skor Aiken's $V$ untuk modul "PILAR" diperoleh dari rentang
0,75 hingga 0,93. Azwar (2017) menyatakan bahwa skor Aiken's $V$ yang lebih dari 0,5 memiliki validitas isi yang baik dengan konten yang dapat diterima dan memuaskan. Hal ini menunjukkan bahwa program "PILAR" memiliki validitas isi yang baik.

Proses selanjutnya adalah uji validasi empirik yang bertujuan untuk mengetahui kemampuan modul dapat berfungsi aplikatif dan berguna dengan baik sesuai dengan kebutuhan peserta (Azwar, 2017). Analisis Wilcoxon signed rank test bertujuan untuk mengetahui perbedaan skor pengetahuan dan keterampilan menyampaikan prevensi KSA.

Hasil analisis skor pengetahuan menggunakan Wilcoxon signed rank test menunjukkan perolehan nilai $Z$ yang diperoleh sebesar -2.952 dengan $p(0,003)<$ 0,01 . Hal ini membuktikan bahwa terdapat perbedaan yang signifikan skor pengetahuan ibu terkait kekerasan seksual anak setelah diberikan pelatihan dengan sebelum diberi pelatihan. Skor pengetahuan setelah diberi pelatihan lebih tinggi dibanding skor pengetahan sebelum pelatihan. Adapun pengaruh effect size pelatihan terhadap pengetahuan sebesar 0,89. Hal ini menunjukkan besar pengaruh pelatihan terhadap peningkatan pengetahuan ibu terkait prevensi KSA sebesar $89 \%$.

Selain skor pengetahuan, perubahan juga terjadi pada variabel keterampilan. Hasil analisis skor keterampilan menggunakan Wilcoxon signed rank test menunjukkan perolehan nilai $\mathrm{Z}$ sebesar - 2,952 dengan $\mathrm{p}(0,003)<$ 0,01 . Hal ini menunjukkan bahwa terdapat perbedaan skor yang signifikan pada skor keterampilan ibu dalam menyampaikan materi prevensi KSA setelah diberikan pelatihan dengan sebelum diberi pelatihan. Pengaruh effect size pelatihan terhadap keterampilan 
dalam menyampaikan prevensi KSA sebesar 0,89. Hal ini menunjukkan besar pengaruh pelatihan terhadap peningkatan keterampilan ibu dalam menyampaikan prevensi KSA sebesar $89 \%$. Berdasarkan hasil yang diperoleh, maka dapat disimpulkan program "PILAR" valid untuk meningkatkan keterampilan ibu dalam menyampaikan materi prevensi KSA.

Untuk mengetahui besarnya selisih perubahan pengetahuan dan keterampilan pada masing-masing partisipan antara sebelum dan setelah diberikan pelatihan dilakukan analisis menggunakan gain score. Hasil analisis gain score dapat dilihat pada Tabel 1.

Tabel 1.

Hasil Gain Score Pengetahuan Prevensi KSA awal sebelum pelatihan sebesar 20 (kategori sedang), kemudian mengalami peningkatan skor sebesar 14 sehingga total skor pengetahuan partisipan $\mathrm{H}$ setelah diberi pelatihan sebesar 34 (kategori tinggi). Sedangkan partisipan yang mengalami peningkatan skor pengetahuan paling rendah adalah partisipan D dengan skor awal sebelum pelatihan sebesar 22 (kategori sedang), kemudian mengalami peningkatan skor sebesar 5 sehingga total skor pengetahuan setelah pelatihan sebesar 27 (kategori tinggi). Adapun besar perubahan skor keterampilan tiap partisipan berdasarkan hasil analisis gain score dilihat pada tabel 2.

\begin{tabular}{cccccc}
\hline Partisipan & Pretest & Kategori & Posttest & Kategori & Gain Score \\
\hline A & 22 & Sedang & 32 & Tinggi & 10 \\
B & 21 & Sedang & 33 & Tinggi & 12 \\
C & 22 & Sedang & 32 & Tinggi & 10 \\
D & 22 & Sedang & 27 & Tinggi & 5 \\
E & 19 & Sedang & 29 & Tinggi & 10 \\
F & 21 & Sedang & 32 & Tinggi & 11 \\
G & 20 & Sedang & 30 & Tinggi & 10 \\
H & 20 & Sedang & 34 & Tinggi & 14 \\
I & 21 & Sedang & 29 & Tinggi & 8 \\
J & 21 & Sedang & 29 & Tinggi & 8 \\
K & 19 & Sedang & 30 & Tinggi & 11 \\
\hline Rata-rata & $\mathbf{2 0 , 7 3}$ & & $\mathbf{3 0 , 6 4}$ & & $\mathbf{9 , 9}$ \\
\hline
\end{tabular}

Tabel 1 menjelaskan bahwa ratarata skor pengetahuan seluruh partisipan setelah pelatihan lebih tinggi sebesar 30,6 daripada rata-rata skor pengetahuan sebelum pelatihan yakni sebesar 20,7. Adapun rata-rata besar kenaikan skor pengetahuan seluruh partisipan yakni sebesar 9,9. Partisipan yang mengalami peningkatan skor pengetahuan paling tinggi adalah partisipan $\mathrm{H}$ dengan skor
Tabel 2 menjelaskan bahwa ratarata skor keterampilan seluruh partisipan setelah pelatihan lebih tinggi yakni sebesar 12 daripada rata-rata skor keterampilan sebelum pelatihan yakni sebesar 6,18. Adapun rata-rata besar kenaikan skor keterampilan seluruhan partisipan yakni sebesar 5,8.

Partisipan yang mengalami peningkatan skor keterampilan paling 
tinggi adalah partisipan E. Partisipan E memiliki skor keterampilan sebelum pelatihan sebesar 7 (kategori sedang), kemudian mengalami peningkataan skor sebesar 11 sehingga skor keterampilan setelah pelatihan sebesar 18 (kategori tinggi). Sedangkan partisipan yang mengalami peningkatan skor keterampilan paling rendah adalah partisipan K. Partisipan K memiliki skor
98\%. Hal ini menunjukkan partisipan menilai proses pelaksanaan pelatihan sangat baik dan memuaskan. Adapun hasil evaluasi dari observer terhadap empat aspek yang sama memperoleh koefisien validitas sebesar $70-95 \%$. Hal ini juga menunjukkan bahwa observer menilai proses pelatihan terlaksana dengan baik dan memuaskan meski ada beberapa kendala teknis.

Tabel 2.

Hasil Gain Score Keterampilan Menyampaikan Prevensi KSA

\begin{tabular}{cccccc}
\hline Partisipan & Pretest & Kategori & Posttest & Kategori & Gain Score \\
\hline A & 9 & Sedang & 13 & Tinggi & 4 \\
B & 7 & Sedang & 13 & Tinggi & 6 \\
C & 7 & Sedang & 11 & Sedang & 4 \\
D & 4 & Rendah & 12 & Sedang & 8 \\
E & 7 & Sedang & 18 & Tinggi & 11 \\
F & 8 & Sedang & 12 & Sedang & 4 \\
G & 10 & Sedang & 14 & Tinggi & 4 \\
H & 3 & Rendah & 10 & Sedang & 7 \\
I & 1 & Rendah & 8 & Sedang & 7 \\
J & 5 & Rendah & 11 & Sedang & 6 \\
K & 7 & Sedang & 10 & Sedang & 3 \\
\hline Rata-rata & $\mathbf{6 , 1 8}$ & & $\mathbf{1 2}$ & & $\mathbf{5 , 8}$ \\
\hline
\end{tabular}

keterampilan sebelum pelatihan sebesar 7 (kategori sedang), kemudian mengalami peningkatan skor sebesar 3 sehingga total skor keterampilan setelah pelatihan sebesar 10 (kategori sedang).

Untuk memperkuat hasil penelitian, evaluasi dilakukan terhadap pelaksanaan pelatihan yang terdiri dari empat aspek yakni fasilitas pelatihan, kualitas fasilitator, proses pelatihan dan kondisi partisipan oleh partisipan dan observer. Hasil evaluasi dari partisipan terhadap empat aspek yakni fasilitas pelatihan, kualitas fasilitator, proses pelatihan dan kondisi partisipan memiliki rentang koefisien validitas sebesar 83-

\section{Diskusi}

Proses validasi isi program "PILAR" berdasarkan formula Aiken's $V$ menghasilkan nilai 0,75 hingga 0,93 . Hal ini menunjukkan bahwa program "PILAR" memiliki validitas isi yang baik karena dinilai mudah dipahami dan indikator tiap aspeknya sesuai dengan tujuan penyusunannya. Sedangkan hasil uji validasi empirik memperoleh nilai $Z=$ -2.952, $p(0,003)<0,01$ untuk pengetahuan partisipan terkait prevensi KSA, dan nilai $Z=-2.952, p(0,003)<0,01$ untuk keterampilan yang dimiliki oleh partisipan dalam menyampaikan materi 
prevensi KSA. Skor pengetahuan dan keterampilan setelah pelatihan yang lebih tinggi dibanding skor pengetahuan dan keterampilan sebelum pelatihan menandakan bahwa hipotesis diterima, artinya program "PILAR" mampu meningkatkan pengetahuan dan keterampilan ibu anak usia dini dalam menyampaikan materi prevensi KSA.

$$
\text { Program "PILAR" yang }
$$

merupakan hasil modifikasi dari program Lingkaran (Mardhiyah, 2017) yang terbukti mampu meningkatkan pengetahuan dan keterampilan ibu menyampaikan prevensi KSA. Hal ini juga didukung oleh Byers, Sears \& Weaver (2008) yang menyatakan bahwa orang tua yang mendapatkan pelatihan terkait prevensi KSA akan lebih memiliki pengetahuan dan keterampilan dalam menyampaikan perlindungan diri pada anak sehingga mampu bersikap positif terhadap kejadian KSA.

Berdasarkan teori belajar Bandura (1986), program "PILAR" dapat meningkatkan pengetahuan dan keterampilan menyampaikan prevensi KSA karena PILAR menekankan pada proses pembelajaran observasional yang terdiri dari 4 tahap yakni atensi, retensi, produksi perilaku dan motivasi. Pada penelitian ini, proses yang pertama kali terjadi adalah atensi yakni saat partisipan memperhatikan dengan fokus dan konsentrasi ketika fasilitator menjelaskan terkait materi pengetahuan kekerasan seksual seksual terhadap anak (KSA) di sesi I, peran orang tua sebagai agen prevensi KSA di sesi II dan prevensi KSA untuk anak usia dini di sesi III. Ketiga sesi ini bertujuan untuk menyampaikan informasi pada partisipan dengan menggunakan metode ceramah, video, film, dan alat peraga. Martin, Kolomitro \& Lam (2013) menyatakan bahwa metode yang variatif seperti ceramah, video dan alat peraga dapat efektif dalam proses pembelajaran. Berdasarkan hasil observasi, rata-rata partisipan cukup antusias dan fokus memperhatikan materi yang dijelaskan.

Proses selanjutnya merupakan retensi. Selama proses pelatihan dari sesi 1 hingga 4, sebagian besar partisipan aktif memberi tanggapan, pertanyaan serta mampu mengerjakan lembar kerja yang diberikan pada tiap sesinya. Seluruh kegiatan tersebut melibatkan proses mengingat kembali informasi dalam bentuk ingatan yang sebelumnya telah dikoding secara simbolik (Bandura, 1986). Dalam hal ini, sebagian besar partisipan mampu memproses informasi yang diperoleh saat memberikan perhatian pada materi dalam bentuk pengetahuan.

Dalam proses pemberian pengetahuan, partisipan mendapatkan verbal persuation dari sumber pengetahuan melalui metode yang digunakan, yakni ceramah interaktif, diskusi, dan tanya jawab. Pemberian pengetahuan pada partisipan selama sesi pelatihan didukung oleh pendapat Bandura (1986) yang menjelaskan bahwa representasi pengetahuan sangat berpengaruh pada tahap awal dan intermediate pengembangan keterampilan. Pengetahuan berisi tentang bagaimana skills yang sesuai dapat dipilih, dikoordinasikan, dan diurutkan supaya sesuai dengan tujuan tertentu untuk menampilkan suatu perilaku.

Proses ketiga merupakan produksi perilaku. Dalam penelitian ini, pengetahuan yang diperoleh dari proses atensi dan retensi diwujudkan dalam bentuk perilaku. Proses pembentukan perilaku terjadi pada sesi IV yakni ibu terampil sampaikan prevensi KSA. Proses pembentukan perilaku baru ini dipadukan dengan teknik behavioral skill training. Menurut Miltenberger (2012) menyatakan bahwa keterampilan baru dapat dibentuk melalui teknik BST yakni 
proses modelling, instruction, rehearsal dan feedback. Pada sesi 4, partisipan melakukan roleplay dengan ada yang berperan sebagai ibu dan anak untuk mempraktikkan cara menyampaikan prevensi KSA. Modelling terjadi pada partisipan ibu menunjukkan cara yang tepat untuk melindungi diri kepada anak, instruction terjadi pada saat partisipan menjelaskan bagian tubuh yang perlu dilindungi beserta cara yang perlu dilakukan untuk melindungi diri pada anak, rehearsal terjadi pada saat ibu meminta anak mengulangi penjelasan yang ibu sampaikan dan feedback terjadi pada saat ibu memberikan apresiasi atau masukan terhadap usaha anak. Teknik behavioral skill training sudah terbukti efektif untuk meningkatkan keterampilan guru dan anak dalam ranah pencegahan KSA pada saat diberi pelatihan (EgemoHelm et al., 2006).

Proses terakhir adalah motivasi. Proses ini merupakan faktor yang membuat perilaku yang sudah terbentuk dapat bertahan sehingga menjadi keterampilan. Dalam pelatihan ini, proses motivasi terjadi pada saat fasilitator dan partisipan saling memberi apresiasi berupa pujian dan tepuk tangan untuk partisipan yang telah mempraktikkan cara menyampaikan prevensi KSA, serta memberikan koreksi dengan bahasa yang baik untuk partisipan yang masih kurang tepat dalam mempraktikkan cara menyampaikan prevensi KSA. Pemberian umpan balik hanya dilakukan oleh fasilitator, sedangkan pemberian umpan balik antar partisipan tidak dilakukan oleh semua partisipan karena waktu yang terbatas dan kesulitan partisipan memberikan umpan balik ke partisipan lainnya. Dari hasil self report, partisipan tampak merasakan banyak manfaat selama mengikuti pelatihan. Hal ini menjadi salah satu faktor yang memotivasi partisipan sehingga efektif dalam pembelajaran.
Selain itu, program "PILAR" yang menggunakan media flashcard dan boneka terbukti dapat memengaruhi atensi dan retensi partisipan sehingga dapat meningkatkan pengetahuan dan keterampilan partisipan dalam menyampaikan prevensi KSA. Hal ini sesuai penelitian Karadag, Dereobah, dan Sonmez (2014) dan Zhang et al. (2014) yang menyatakan bahwa program menggunakan berbagai media seperti boneka, kartu bergambar, dan roleplay yang diberikan pada anak usia dini mampu meningkatkan pengetahuan dan keterampilan melindungi diri dari KSA.

Penyusunan program "PILAR" yang mengikuti aturan penyusunan modul menurut Russel dan Johanningsmeier (1981) menjadi salah satu faktor yang memengaruhi keberhasilan program. Di antaranya adalah pemilihan partisipan yang didasarkan pada karakteristik tertentu untuk memperkuat alasan bahwa perubahan yang terjadi pada partisipan disebabkan oleh pemberian perlakuan. Selain itu, bahasa yang digunakan dalam pelatihan adalah bahasa yang mudah diterima oleh usia ibu. Pemilihan media pendukung juga didasarkan pada karakteristik partisipan yang mudah didapatkan oleh partisipan ibu-ibu.

Faktor lain yang memengaruhi keberhasilan program adalah pemilihan metode pembelajaran. Metode pembelajaran observasional yang digunakan dalam pelatihan telah terbukti efektif diterapkan pada proses belajar baik anak maupun dewasa (Miltenberger, 2012). Metode belajar observasional melalui modelling salah satu metode yang dinilai efektif untuk diterapkan dalam meningkatkan pengetahuan (Salisu \& Ransom, 2014).

Selain itu, faktor lain yang memengaruhi efektivitas program pelatihan pada peningkatan pengetahuan 
dan keterampilan adalah pemilihan model yang sudah sesuai dengan karakteristik ideal. Fasilitator yang berperan sebagai model dapat memberi stimulus bagi partisipan untuk belajar membentuk perilaku baru (Bandura, 1986). Fasilitator yang dipilih merupakan psikolog yang memiliki banyak pengalaman dalam memberikan pelatihan terkait KSA serta memiliki pengalaman dalam memberikan pelatihan pada ibu-ibu. Bandura (1986) menyatakan bahwa model yang memiliki kemampuan dan kompetensi yang baik cenderung lebih mudah ditiru oleh orang lain dalam proses pembelajaran.

\section{Kesimpulan}

Program "PILAR" terbukti mampu meningkatkan pengetahuan dan keterampilan ibu menyampaikan prevensi KSA. Program "PILAR" dinilai memiliki validitas isi dan empirik yang baik. Hal ini menunjukkan bahwa program "PILAR" mempunyai kesesuaian materi, mudah dipahami dan aplikatif sebagai sebuah program yang bertujuan untuk meningkatkan pengetahuan dan keterampilan ibu yang memiliki anak usia 46 tahun dalam menyampaikan prevensi KSA.

\section{Saran}

Terdapat beberapa saran dari Program "PILAR", yaitu a) program "PILAR" dapat dijadikan sebagai bahan rujukan untuk proses sosialisasi kepada ibu yang memiliki anak usia dini melalui sekolah, instansi kesehatan atau masyarakat guna meningkatkan pengetahuan keterampilan ibu menyampaikan prevensi KSA pada anak. b) pengembangan program "PILAR" selanjutnya dapat dilakukan dengan cara uji efektivitas pada variabel lain dengan jumlah partisipan yang banyak desain penelitian yang berbeda, kota yang berbeda atau dengan partisipan ibu dengan karakteristik anak yang berbeda. c) perlunya memperhatikan halhal teknis pada pelaksanaan pelatihan sebagai pengembangan program "PILAR" selanjutnya guna meminimalisasi faktorfaktor yang dapat memengaruhi hasil penelitian.

\section{Kepustakaan}

Azwar, S. (2017). Metode penelitian. Yogyakarta: Pustaka Pelajar.

Bandura, A. (1986). The explanatory and predictive scope of self-efficacy theory. Journal of Social and Clinical Psychology, 4(3), 359-373. doi: 10.1521/jscp.1986.4.3.359

Bartholomew, L. K., Gottlieb, N., Kok, G., \& Parcel, G. S., (2006). Planning health promotion programs: An intervention mapping approach (Edisi kedua). San Francisco: Jossey-Bass.

Berhane Y., Devries K., Deyessa N., Durand, J., Ellsberg, M., GarciaMoreno C., Heise, L., Jansen H., Kiss L, Mbwambo, J., Schraiber, LB.,Watts, C, \& Yoshihama, M. (2011). Violence against women is strongly associated with suicide attempts: Evidence from the WHO multi-country study on women's health and domestic violence against women. Social Science \& Medicine, 73(1), 79-86. doi: 10.1016/j.socscimed.2011.05.006

Brown, H. D. (1973). Prinsiples of languaege learning and teaching. New Jersey: Prentice Hall, Englewood Cliff

Byers, E. S., Sears, H. A., \& Weaver, A. D. (2008). Parents' reports of sexual communication with children in kindergarten to grade 8. Journal of Marriage and Family, 70(1), 86-96. doi: 10.1111/j.1741-3737.2007.00463.x

Cashmore, J \& Shackel, R. (2014). Gender differences in the context and consequences of child sexual abuse. 
Current Issues in Criminal Justice, 24(1), 75-104. doi: $\underline{10.1080 / 10345329.2014 .12036008}$

Chalya, P. L., Mlekwa, F. M., Nyamhanga, T., \& Urassa, D. (2016). Knowledges, attitudes and practices of parents on child sexual abuse and its prevention in Shingaya district, Tanzania. Tanzania Journal of Health Research, 18(4), 1-9. doi: 10.4314/thrb.v18i4.6

Egemo-Helm, K., Johnson, B. M., Jostad, C., Kelso, P., Knudson, P. \& Langley, L. Miltenberger, R. G. (2006). A preliminary of two behavioral skills training procedures for teaching abduction-prevention skill to schoolchildren. Journal of Applied Behavioral Analysis, 39(1), 25-34. doi: 10.1901\%2Fjaba.2006.167-04

Finkelhor, D., Shattuck, A., Turner, H. A. \& Hamby, S. L. (2014). The lifetime prevalence of child sexual abuse and sexual assault assessed in late adolescence. Journal of Adolescent Health, 55(3), 329-333. doi: j.jadohealth.2013.12.026

Reisener, C. D., Gadke, D. L., Ho, T. Q., \& Jostad, C. M. (2014). The effect of behavioral skills training on teacher's implementation guided compliance. Journal of Psychology $\mathcal{E}$ Behavioral Science, 2(3\&4), 1-16. doi: 10.15640/jpbs.v2n3-4a1

Hunt, D. P. (2003). The concept of knowledge and how to measure it. Journal of Intellectual Capital, 4(1), 100-113. doi: $\underline{10.1108 / 14691930310455414}$

Indriati E. (2001). Child sexual abuse (pencabulan terhadap anak): Tinjauan klinis dan psikologis. Berita Ilmu Kedokteran, 33(2), 111-119.

Islawati, I., \& Paramastri, I. (2015). Program "Jari Peri" sebagai pelindung anak dari kekerasan seksual. Jurnal Psikologi, 42(2), 115128. doi: $\underline{10.22146 / j p s i .7167}$

Karadag, S. Ç., Dereobah, N., \& Sonmez, S. (2014). An Investigation of preschool teachers' recognition of possible child abuse and neglect in Izmir, Turkey. Journal of Interpersonal Violence, 30(5), 873-891. doi: $10.1177 / 0886260514536274$

Kisanga, F. (2012). Child sexual abuse in urban Tanzania: Possibilities and barriers for prevention. Tanzania : Muhimbili University of Health and Allied Sciences School of Public Health and Social Sciences

Komalasari, E. (2016). Skill-based curriculum development to prevent the violence against children. Indonesian Journal of Islamic Early Childhood Education, 1(1), 101-108.

Komisi Perlindungan Anak Indonesia (KPAI). (2016). Diakses pada tanggal $4 \quad$ Juli 2018 melalui http://bankdata.kpai.go.id/author/kp ai

Mardhiyah, Z. (2017). Validasi program "Lingkaran" untuk meningkatkan keterampilan ibu dalam menyampaikan prevensi kekerasan seksual pada anak. (Tesis tidak dipublikasikan). Yogyakarta : Universitas Gadjah Mada.

Martin, B. O., Kolomitro, K. \& Lam, T. (2013). Training methods: A review and analysis. Human Resource Development Review 13(1), 11-35. doi: 10.1177\%2F1534484313497947

Miltenberger, R. G. (2012). Behavior modification (principles and procedures) (Edisi kelima). USA: Wadsworth Cengage Learning.

Noval, D. (2018). Kasus kekerasan seksual terhadap anak tertinggi di Jawa Timur. Diakses pada tanggal 19 Juli 2018 melalui https://online.jatim.metrotvnews/kas 
us-kekerasan-seksual-terhadapanak-tertinggi-di-jawa-timur-bNPX

Odhayani, A. A, Watson, W. J. \& Watson, L. (2013). Behavioral consequences of child abuse. Canadian Family Physician, 59(8), 831-836.

Ogunfowokan, A \& Fajemilehin, R. B. (2012). Impact of a school-based sexual buse prevention education program on the knowledge and attitude of high school girls. Journal of School Nursing, 28(6), 459-468. doi: $\underline{10.1177 / 1059840512446949}$

Olafson, E. (2011). Child sexual abuse: Demography, impact, and interventions. Journal of Child $\mathcal{E}$ Adolescent Trauma, 4(1), 8-21. doi: $\underline{10.1080 / 19361521.2011 .545811}$

Russell, J. D. \& Johanningsmeier, K. A. (1981). Improving competence through Programar instruction. Toronto: Kendal/ Hunt Publishing Company.

Salisu, A. \& Ransom, E, N. (2014). The role of modeling towards impacting quality education. International Letters of Social and Humanistic Sciences, 32, 54-61. doi: 10.18052/www.scipress.com/ILSHS. $\underline{32.54}$

Scimeca, G., Ventimiglia, M.A., Bruno, A., Pandolfo, G., Cicciarelli, C., Zoccali, R. \& Muscatello, M. (2014). Abuse characteristics and posttraumatic stress disorder among child and adolescents victims of sexual abuse: A preliminary investigation. Annals of Depression and Anxiety, 1(4), 1-3.

Walsh, K., \& Brandon, L. (2012). Their children's first educators: Parents' views about child sexual abuse prevention education. Journal of Child and Family Studies, 21(5), 734746. doi: $10.1007 / \mathrm{s} 10826-011-9526-4$

Yafie, E. (2017). Peran ibu dalam memberikan pendidikan seksual anak usia dini. Jurnal CARE (Children Advisory Research and Education), 4(2), 18-30.

Yandu, B.W. (2017). Validasi Program ORIGAMI pada orangtua untuk prevensi kekerasan seksual anak tunarungu. (Tesis tidak dipublikasikan). Yogyakarta: Universitas Gadjah Mada

Zhang, W., Chen, J., Feng, Y., Li, J., Zhao, X., \& Luo, X. (2013). Young children's knowledge and skills related to sexual abuse prevention: a pilot study in Beijing, China. Child Abuse \& Neglect, 37(9), 623-630. doi: 10.1016/j.chiabu.2013.04.018 